\title{
Foraging patterns of two syngnathid fishes: importance of harpacticoid copepods
}

\author{
Kevin Tipton, Susan S. Bell \\ Department of Biology, University of South Florida, Tampa, Florida 33620, USA
}

\begin{abstract}
The diets of juvenile $(<90 \mathrm{~mm})$ Syngnathus scovelli and of Hippocampus zosterae, abundant members of a resident fish community in a Thalassia testudinum seagrass bed in Tampa Bay, Florida, were examined from April to October 1984. Harpacticoid copepods comprised most of the diet, both in terms of percent number and percent biomass, for the smaller size classes of $S$. scovelli and for $H$. zosterae, and harpacticoids generally had the highest index of relative importance (IRI) for both syngnathids. S. scovelli displayed ontogenetic switching to larger food items, such as amphipods, shrimp and crustacean eggs. Harpacticus sp. 1 was the most common harpacticoid copepod species found in the guts of the 2 syngnathids, but was only rarely encountered in prey samples from seagrass blades. Three other harpacticoids, Paradactylopodia brevicornis sp., Dactylopodia tisboides and Harpacticus sp. 2 had high IRIs in H. zosterae but not in S. scovelli. Vanderploeg \& Scavia's selectivity index $\left(E^{*}\right)$ was calculated for sampling dates when both species of syngnathids were most abundant, using prey density on seagrass blades as a measure of prey availability. Only the harpacticoid Harpacticus sp. 1 had high positive selectivity values.
\end{abstract}

\section{INTRODUCTION}

Fish predation on macrofaunal invertebrates in both temperate and tropical seagrass beds is well studied (Reid 1954, Carr \& Adams 1973, Young et al. 1976. Brook 1977, Nelson 1979, Stoner 1979, 1980, 1982, Stoner \& Livingston 1980, Ryer 1981, Livingston 1982, 1984, Ryer \& Boehlert 1983). However, a gap exists in information on predation on meiofauna by fishes within such sites. Meiofauna are abundant in seagrass beds (Bell et al. 1984), with as many as 3000 harpacticold copepods reported from a single blade of Thalassia testudinum Banks ex König (M.O. Hall pers. comm.). Given the great abundance of copepods on blades, in combination with that of typical sediment dwelling forms, meiofauna may serve as important trophic links in seagrass beds.

Some investigators have reported harpacticoid copepods to be unimportant to higher trophic levels (Marshall 1970, McIntyre \& Murison 1973, Heip \& Smol 1976), but these studies are from unvegetated areas. More recent work from shallow water has shown that harpacticoids are a prevalent dietary item for some fishes, especially juveniles and smaller-sized species (e.g. Feller \& Kaczynski 1975, Bodiou \& Villiers 1979
Alheit \& Scheibel 1982, Zander 1982). While such studies combine to illustrate trophic links between harpacticoids and fishes, few studies are from seagrass beds. Information on fish feeding on harpacticoids in seagrass beds has been gleaned mostly from subtropical areas, specifically Florida (Table 1). Two limitations of previous studies are obvious. First, few data have been recorded on prey (meiofauna) availability (see Petraitis 1979 for discussion), an important aspect of feeding studies. Second, no investigation on fish feeding on meiofauna in seagrass beds has identified prey to species level, an analytical problem with studies of fish feeding on invertebrates in general (see Stoner 1979). Species level information, however, is vital for detailed understanding of benthic food selection by fishes.

Members of the family Syngnathidae (pipefishes and seahorses) are consistently abundant members of seagrass fish communities (Reid 1954, Carr \& Adams 1973 , Adams 1976, Kulczycki et al. 1981, Ryer 1981, Sogard 1982, Huh 1984, Livingston 1984, Targett 1984, Howard \& Koehn 1985). Little is known about the ecology of syngnathids (Howard \& Koehn 1985), with most information being anecdotal. Aspects of seahorse life history have been noted (Strawn 1958), but the feeding ecol- 
Table 1 Overview of fish feeding studies reporting predation on harpacticoid copepods in seagrass beds

\begin{tabular}{|c|c|c|c|c|c|}
\hline Location & Fish species/size & $\begin{array}{l}\text { Fish } \\
\text { collection } \\
\text { methods }\end{array}$ & $\begin{array}{l}\text { Expression of im- } \\
\text { portance values }\end{array}$ & Conclusion & Source \\
\hline $\begin{array}{l}\text { North } \\
\text { Carolina } \\
\text { USA }\end{array}$ & $\begin{array}{l}\text { Lagodon rhomboides } \\
\text { Orthopristis chrysoptera }\end{array}$ & Bag seine & $\begin{array}{l}\% \text { Body weight } \\
\text { of fish }\end{array}$ & $\begin{array}{l}\text { Harpacticoid eaten by } \\
\text { small fishes }\end{array}$ & Adams 1976 \\
\hline Australia & $\begin{array}{l}\text { Sillaginodes punctatus } \\
25-320 \mathrm{~mm}\end{array}$ & Seine & $\begin{array}{l}\text { Percent volume } \\
(\% \mathrm{~V})\end{array}$ & $\begin{array}{l}\text { Harpacticoids important } \\
\text { to } 0+\text { age class }\end{array}$ & Robertson 1977 \\
\hline $\begin{array}{l}\text { Florida } \\
\text { USA }\end{array}$ & $\begin{array}{l}\text { Anchoa mitchelli } 10-69 \mathrm{~mm} \\
\text { Leiostomus xanthurus } \\
10-109 \mathrm{~mm} ; \\
\text { Micropogonius undulatus } \\
10-119 \mathrm{~mm} ; \\
\text { size classes vary according to } \\
\text { species }\end{array}$ & Otter trawl & $\begin{array}{l}\% \text { Dry weight } \\
(\% \mathrm{DW})\end{array}$ & $\begin{array}{l}\text { Harpacticoids important } \\
\text { to juvenile } L \text {. xanthurus }\end{array}$ & $\begin{array}{l}\text { Sheridan \& } \\
\text { Livingston } 1979\end{array}$ \\
\hline $\begin{array}{l}\text { Florida } \\
\text { USA }\end{array}$ & $\begin{array}{l}\text { Lagodon rhomboides } \\
11-121 \mathrm{~mm}, 5 \mathrm{~mm} \text { size } \\
\text { classes }\end{array}$ & Trawl & $\%$ DW & $\begin{array}{l}\text { Harpacticoids important } \\
\text { to smaller size classes }\end{array}$ & $\begin{array}{l}\text { Stoner } 1979 \\
1980\end{array}$ \\
\hline $\begin{array}{l}\text { Florida } \\
\text { USA }\end{array}$ & $\begin{array}{l}\text { Callionymus pauciradiatus } \\
5-38 \mathrm{~mm}\end{array}$ & Pushnet & $\begin{array}{l}\% \text { Frequency, } \\
\% \text { Number, } \\
\% \text { DW, } \\
\text { Chesson's electivity }\end{array}$ & $\begin{array}{l}\text { Harpacticoids most im- } \\
\text { portant prey for all size } \\
\text { classes; positive selec- } \\
\text { tion for harpacticoids }\end{array}$ & $\begin{array}{l}\text { Sogard } 1982 \\
1984\end{array}$ \\
\hline $\begin{array}{l}\text { Florida } \\
\text { USA }\end{array}$ & $\begin{array}{l}14 \text { species for quantitative, } \\
12 \text { species for qualitative } \\
\text { analysis; size classes vary } \\
\text { according to species }\end{array}$ & Otter trawl & $\begin{array}{l}\% \text { DW, } \\
\text { cluster analysis }\end{array}$ & $\begin{array}{l}\text { Small or young stages of } \\
\text { species eat harpacticoids }\end{array}$ & $\begin{array}{l}\text { Livingston } \\
1982,1984\end{array}$ \\
\hline $\begin{array}{l}\text { Florida } \\
\text { USA }\end{array}$ & $\begin{array}{l}\text { Diplodus holbrooki } \\
\text { Lagodon rhomboides } \\
11-121+\mathrm{mm}, 5 \mathrm{~mm} \text { size } \\
\text { classes }\end{array}$ & Trawl & $\% \mathrm{DW}$ & $\begin{array}{l}\text { Harpacticoids important } \\
\text { to smaller size classes of } \\
\text { both species }\end{array}$ & $\begin{array}{l}\text { Stoner \& } \\
\text { Livingston } 1984\end{array}$ \\
\hline $\begin{array}{l}\text { North } \\
\text { Carolina } \\
\text { USA }\end{array}$ & $\begin{array}{l}\text { Lagodon rhomboides } \\
\text { Leiostomus xanthurus } \\
\text { Menidia menidia } \\
\text { Orthopristis chrysoptera }\end{array}$ & Otter trawl & Ivlev's electivity & $\begin{array}{l}\text { M. menidia avoid Euter- } \\
\text { pina. Harpacticoids im- } \\
\text { portant to juveniles of } \\
3 \text { species }\end{array}$ & Fulton 1985 \\
\hline Australia & $\begin{array}{l}\text { Mitotichthys semistriatus } \\
\text { Vanacampus phillipi } \\
\text { Urocampus carinorostris; } \\
\text { size classes vary according to } \\
\text { species }\end{array}$ & Beam trawl & $\% \mathrm{~V}$ & $\begin{array}{l}\text { Harpacticoids important } \\
\text { to U. carinorostris }\end{array}$ & $\begin{array}{l}\text { Howard \& } \\
\text { Koehn } 1985\end{array}$ \\
\hline
\end{tabular}

ogy of these fish is virtually unreported. Livingston (1984) and preliminary investigations in a Tampa Bay seagrass bed (Tipton 1987) have shown that the gulf pipefish Syngnathus scovelli Evermann \& Kendall and the dwarf seahorse Hippocampus zosterae Jordan \& Gilbert feed during the daytime and are consumers of large numbers of harpacticoids. The purpose of this study was to investigate the feeding ecology of 2 species of syngnathids in a subtropical Thalassia testudinum bed over a 6 mo period with special reference to meiobenthic copepod prey. Specifically we examine ontogenetic patterns of feeding of prey for major taxa and meiobenthic copepod species and prey selectivity by syngnathids during times of peak fish abundances.

\section{MATERIALS AND METHODS}

Study site. Fishes and epifaunal crustaceans, representing 'available prey', were collected from a subtidal site at the south end of the Sunshine Skyway bridge causeway near the mouth of Tampa Bay, Florida $\left(27^{\circ}\right.$ $\left.35^{\prime} \mathrm{N}, 82^{\circ} 36^{\prime} \mathrm{W}\right)$. Seagrass beds, composed primarily of Thalassia testudinum, dominated the site (approximately $10 \times 10^{5} \mathrm{~m}^{2}$ ), but patches of Halodule wrightii (Ascherson) were common in nearshore areas. Drift algae, mainly Acanthophora sp., Gracilaria sp. and Hypnea sp., were prominent over the study period throughout the entire seagrass bed. Sediments were muddy-sand and water depths during this study 
ranged from ca 0.25 to $1.0 \mathrm{~m}$. Salinity ranged from 31 to $34 \%$ and temperature was 24 to $32{ }^{\circ} \mathrm{C}$ over the study period.

Field sampling. Collections of fishes were made during daylight hours $(10: 00$ to $18: 00 \mathrm{~h})$ twice monthly from April to October 1984. Fishes were collected with a $92.0 \mathrm{~cm}$ wide, $1 \mathrm{~mm}$ mesh pushnet from randomly selected $100 \mathrm{~m}^{2}$ plots within the Thalassia testudinum bed. While the pushnet may underestimate the abundance of large and mobile fishes, it is an efficient method of collecting small and cryptic species, such as gobies, blennies, pipefishes and seahorses, which live in seagrass beds (Strawn 1954). Five $20 \mathrm{~m}$ long pushnet runs were made through each plot. Two plots were sampled on dates when few fish (i.e. less than 20 Syngnathus scovelli $<90 \mathrm{~mm}$ ) were captured in the first plot. Fishes were preserved immediately in $10 \%$ buffered formalin-seawater. Fishes were not anaesthetized and no regurgitation was observed.

Laboratory procedures. All fishes caught in pushnet samples were enumerated and identified to species. The standard length of each Syngnathus scovelli was measured to the nearest millimeter and individuals $<90 \mathrm{~mm}$ (that size found to have eaten large numbers of harpacticoid copepods in preliminary investigations) were saved for gut analysis. Hippocampus zosterae were measured to the nearest millimeter from the top of the head crest to the tip of the tail (Strawn 1958) and all individuals were retained for gut analysis.

Syngnathids have a tubelike gut with no differentiation between the stomach and intestines, so the entire gut of both Syngnathus scovelli and Hippocampus zosterae was examined for investigation of feeding habits. The gut was removed from each fish and placed into a solution of $70 \%$ isopropanol and Rose-Bengal stain. Following staining, guts were examined under a dissecting microscope. Prey were identified, enumerated and measured to the nearest $0.04 \mathrm{~mm}$ with an ocular micrometer and dissecting microscope. Most prey were identified at least to the ordinal level and harpacticoid copepods were identified to the species level. A prey category of unidentifiable copepods was made up to include those copepods (cyclopoid and harpacticoid) which could not be identified due to digestion. Each major prey taxon was assigned a morphotype and each species of harpacticoid copepod found was assigned to one of 6 harpacticoids morphotypes based upon body shape. Guts of all S. scovelli and H. zosterae up to a maximum of 20 of each species, including all size classes, from each sampling date were examined. A total of 205 juvenile $S$. scovelli and $87 \mathrm{H}$. zosterae guts were included in this study.

Dietary analysis. The frequency of occurrence (\% F) and percent composition by number $(\% \mathrm{~N})$ were determined for each prey taxon. Since percent composition by number tends to overemphasize the contribution of small dietary items, the percent composition by dry weight biomass ( $\% \mathrm{DW}$ ) of prey was determined to provide a complete description of the diet (Hyslop 1980). To summarize the data the $\% \mathrm{~F}, \% \mathrm{~N}$ and $\% \mathrm{DW}$ were used to calculate an index of relative importance (IRI) (Pinkas et al. 1971). The IRI was calculated as follows:

$$
\text { IRI }=(\% \mathrm{~N}+\% \mathrm{DW})(\% \mathrm{~F}) .
$$

Dry weight biomass of prey was estimated from measurements on field-collected organisms. Freshly collected organisms from the study site were returned to the laboratory for biomass analyses. Freshly killed individuals were used because of possible error introduced into dry weight estimates by preservation or freezing of samples (Williams \& Robins 1982). Organisms were anaesthetized with an isotonic solution of $\mathrm{MgCl}_{2}$ assigned to a morphotype, measured and assigned length classes. Each organism was rinsed in deionized water and batches of 5 to 20 individuals of each size class were placed on preweighed aluminum pans. The pans and their contents were weighed after drying in an oven for 24 h at $60^{\circ} \mathrm{C}$. Cyclopoid copepods, harpacticoid copepods and ostracods were weighed on a Cahn 29 electrobalance $( \pm 0.1 \mu \mathrm{g})$. Larger taxa were weighed on a Mettler balance ( $\pm 0.01 \mathrm{mg}$ ). These weights were then used to calculate length-weight regressions for each morphotype and provide estimates of prey biomass. If the length-weight regression for a morphotype was non-significant $(p>0.05)$ the mean weight of the morphotype was used for biomass estimates. Regression equations derived by Williams \& Robins (1982) and Sogard (1982) were used for calanoid copepods and amphipods, respectively.

Estimates of prey 'availability', were made by sampling blades of Thalassia testudinum from within the $100 \mathrm{~m}^{2}$ plots where fish were collected on the 6 dates when both species of syngnathids were most abundant (see below). Blades were haphazardly selected and sampled prior to the fish collections. A plastic tube with a $0.063 \mathrm{~mm}$ mesh on one end was filled with filtered seawater, placed over a seagrass blade and corked. The grass blade and all epifaunal organisms trapped in the tube were washed into a jar and preserved with $10 \%$ buffered formalin-seawater with Rose-Bengal stain. The samples were returned to the laboratory and crustaceans from 4 blades from each sampling date were identified and enumerated. Harpacticoid copepods were identified to species and all other organisms were identified to lowest possible taxon.

Selectivity was determined using faunal abundances from seagrass samples, and gut contents of the syngnathids. Vanderploeg \& Scavia's relativized electivity index $\left(E^{*}\right)$ (Vanderploeg \& Scavia 1979) was calculated as: 


$$
\begin{aligned}
& W_{\mathrm{i}}=\left(R_{\mathrm{i}} / P_{\mathrm{i}}\right) / \sum_{\mathrm{i}}\left(R_{\mathrm{i}} / P_{1}\right) \\
& E^{*}=\left[W_{1}-(1 / N)\right] /\left[W_{1}+(1 / N)\right]
\end{aligned}
$$

where $R_{\mathrm{i}}=$ proportion of food item in the diet; $P_{\mathrm{i}}=$ proportion of food item in the environment; and $N=$ number of kinds of food items.

$E^{*}$ values range between +1 and -1 ; a range of +0.3 to -0.3 was arbitrarily chosen to indicate random' selection. Positive values above +0.3 indicate selection of prey items and negative values below -0.3 indicate avoidance. A necessary assumption, based on laboratory observations, of the above approach is that fauna on seagrass blades represented 'available' prey. Syngnathus scovelli, observed in aquaria, actively searched for prey by swimming among and striking at prey on seagrass blades or in the water column with fairly equal frequency. Hippocampus zosterae, however, attached themselves to seagrass blades with their prehensile tails and attacked blades more frequently than the water column (Tipton unpubl.).

Unlike other selectivity indices that vary with the relative abundance of other food items in the sample (Chesson 1978, Vanderploeg \& Scavia 1979, Lechowitz $1982), E^{*}$ is unaffected by the relative abundance of prey types and is probably the best overall selectivity index (Lechowitz 1982). In this study $E^{*}$ was calculated by combining data from 3 sampling dates in spring and 3 sampling dates in summer. Three dates were lumped so that all available prey were represented by a sufficient number and no $E^{*}$ values were undefined when prey in the environment were equal to zero $\left(P_{1}=0\right)$. These dates were chosen because they contained the highest number of both Syngnathus scovelli and Hippocampus zosterae. $E^{*}$ values were calculated for 4 size classes of $S$. scovelli and 3 size classes of H. zosterae for both spring and summer. Prey selection was calculated from numerical percentages. Organisms such as isopods, insects, and mites were not included in analysis as they represented $<1 \%$ of both the available prey and the gut contents. Most crustacean eggs found in the guts were larger than copepods (shrimp or amphipod eggs?) and were not included in the calculations of $E^{*}$ because no practical way to quantitatively sample their 'availability' exists.

\section{RESULTS}

\section{Dietary analysis of Syngnathus scovelli}

Harpacticoid, cyclopoid and calanoid copepods consistently had the highest percent frequencies of occurrence $(\% \mathrm{~F})$ in guts of all size classes of Syngnathus scovelli (Table 2). Amphipods, shrimp, ostracods and crustacean eggs showed increased percent frequencies of occurrence with increasing length of $S$. scovelli. Significant differences in both \% $\mathrm{N}$ and \% DW of the harpacticoid, cyclopoid and unidentified copepod prey items were detected among the 4 size classes of Syngnathus scovelli (Fig. 1; Kruskal-Wallis test, $p<0.05$ ). Inspection of the data shows a strong pattern of higher percentages of both number and dry weight of these prey in the smaller size classes of fish (Fig. 1). The \% N and \% DW of crustacean eggs and shrimp were also significantly different among the 4 size classes of $S$. scovelli but, in contrast, more of these prey were consumed by the larger size classes (Fig. 1). No other differences in either $\% \mathrm{~N}$ or $\% \mathrm{DW}$ were recorded for remaining prey among the size classes of $S$. scovelli.

Harpacticoid copepods had the highest index of relative importance (IRI) value of any prey for all sizes of Syngnathus scovelli (Table 3). A value of 10427 (maximum IRI $=20000$ ) was obtained for harpacticoids in the $30-49 \mathrm{~mm}$ size class of $S$. scovelli. Harpacticoids were the most important prey for the 2 smallest size classes while crustacean eggs had the highest IRIs for the 50-69 and $70-89 \mathrm{~mm}$ size classes. Calanoid copepods and caridean shrimp also had high IRIs for

Table 2. Syngnathus scovelli. Percent frequency of occurrence ( $\%$ F) of major prey taxa for 4 size classes of fish. Number of guts examined is given in parentheses for each size class. Total $=\% \mathrm{~F}$ for all size classes combined

\begin{tabular}{lccccc|}
\hline Prey taxon & \multicolumn{5}{c}{ Size class in mm } \\
& $<30$ & $30-49$ & $50-69$ & $70-89$ \\
$(n=36)$ & $(n=46)$ & $(n=58)$ & $(n=39)$ & Total \\
\hline Amphipods & 0.0 & 39.1 & 62.1 & 92.3 & 50.3 \\
Calanoid copepods & 72.2 & 76.1 & 89.7 & 94.9 & 83.8 \\
Cyclopoid copepods & 52.8 & 65.2 & 46.6 & 46.2 & 52.5 \\
Harpacticoid copepods & 72.2 & 93.5 & 87.9 & 64.1 & 86.0 \\
Crustacean eggs & 2.8 & 21.7 & 67.2 & 23.1 & 9.5 \\
Ostracods & 0.0 & 4.4 & 10.3 & 56.4 & 24.6 \\
Caridean shrimp & 2.8 & 8.7 & 29.3 & 35.9 & 36.9 \\
Unidentified copepods & 13.9 & 39.1 & 50.0 & \\
\hline
\end{tabular}



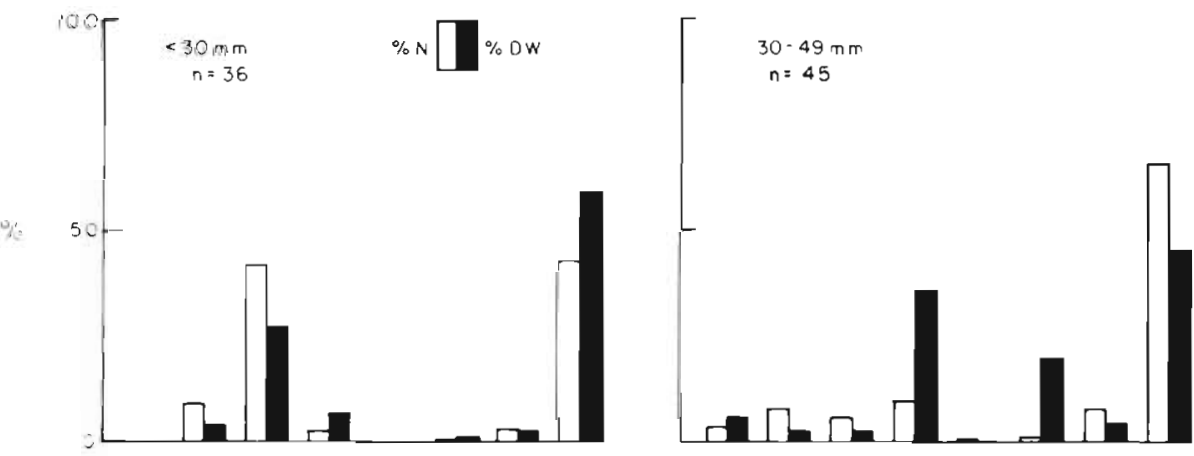

Fig. 1. Syngnathus scovelli. Percentage number and percentage dry weight biomass for prey items in guts of 4 size classes of fish over all dates combined. Number of guts examined (n) is given for each size class. AM: amphipods; $\mathrm{CA}$ : calanoid copepods; $C Y$ : cyclopoid copepods; CE: crustacean eggs; OS: ostracods; SH: caridean shrimp; UC: unidentified copepods; HC: harpacticoid copepods
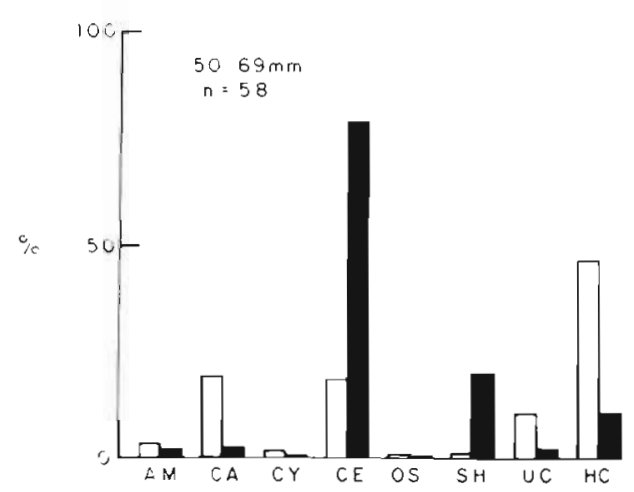

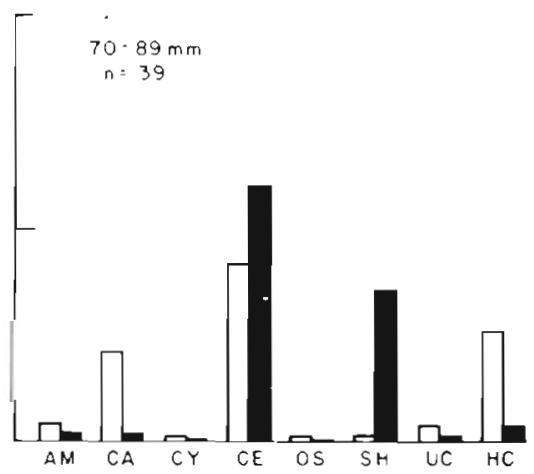

the largest size class and cyclopoid copepods had the 2nd highest IRI for the $<30 \mathrm{~mm}$ size class. Other prey were not important components of $S$. scovelli diets.

No strong seasonal differences in dietary composition of Syngnathus scovelli over the dates was apparent with crustacean eggs and harpacticoids constituting the majority of the diet on most sampling dates (data available in Tipton 1987). Additionally the IRI values for major prey of $S$. scovelli did not show any differences among seasons mirroring the trends for abundance and biomass of food items (Tipton 1987).

The IRI of Harpacticus sp. 1, the dominant species of harpacticoid copepod found in guts, closely followed that of total harpacticoids for all 4 size classes of Syngnathus scovelli (Fig. 2 and 3). Other species of harpac- ticoids with high importance values were Harpacticus sp. 2, Ectinosomatid sp. B and unidentified copepodites.

\section{Dietary analysis of Hippocampus zosterae}

Every Hippocampus zosterae examined contained harpacticoid copepods (Table 4). Calanoid copepods and unidentified copepods also had high \% F values. Amphipods increased in frequency of occurrence from the smallest size class (13.3\%) to the largest size class $(44.7 \%)$. Other prey did not have high \% F values in $H$. zosterae, except for cyclopoid copepods (44.4\%) for the $20-30 \mathrm{~mm}$ size class.

Table 3. Syngnathus scovelli. Index of Relative Importance (IRI) of major prey taxa for 4 size classes of fish. Number of guts examined is given in parentheses for each size class. (Maximum IRI $=2.0 \times 10^{4}$ ). Mean $=$ IRI over all sizes classes combined

\begin{tabular}{|c|c|c|c|c|c|}
\hline \multirow[t]{2}{*}{ Prey taxon } & \multicolumn{4}{|c|}{ Size class in $\mathrm{mm}$} & \multirow[b]{2}{*}{ Mean } \\
\hline & $\begin{array}{c}<30 \\
(n=36)\end{array}$ & $\begin{array}{c}30-49 \\
(n=46)\end{array}$ & $\begin{array}{c}50-69 \\
(n=58)\end{array}$ & $\begin{array}{c}70-89 \\
(n=39)\end{array}$ & \\
\hline Amphipods & 0 & 352 & 353 & 494 & 301 \\
\hline Calanoid copepods & 997 & 765 & 1746 & 2206 & 1443 \\
\hline Cyclopoid copepods & 3662 & 503 & 82 & 48 & 893 \\
\hline Harpacticoid copepods & 7422 & 10427 & 5015 & 2531 & 6349 \\
\hline Crustacean eggs & 24 & 711 & 5591 & 6509 & 3417 \\
\hline Ostracods & 0 & 47 & 1 & 7 & 14 \\
\hline Caridean shrimp & 2 & 43 & 588 & 2028 & 644 \\
\hline Unidentified copepods & 63 & 450 & 633 & 124 & 176 \\
\hline
\end{tabular}



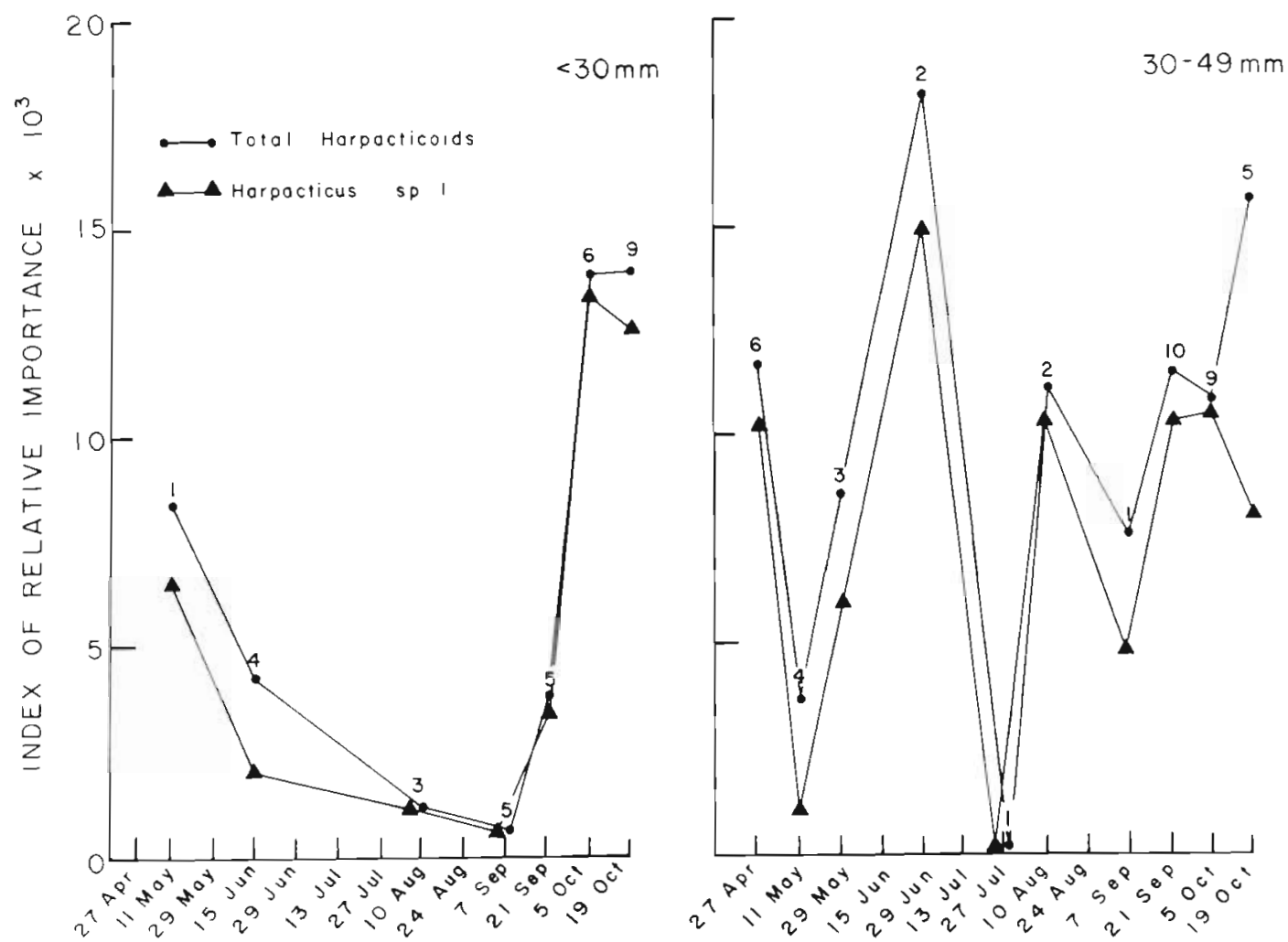

Fig. 2. Syngnathus scovelli. Temporal variation of Index of Relative Importance (IRI) values for total harpacticoid copepods and Harpacticus sp. 1 for the $<30 \mathrm{~mm}$ and $30-49 \mathrm{~mm}$ size classes. Numbers of guts examined are indicated above data points. Maximum IRI $=2.0 \times 10^{4}$
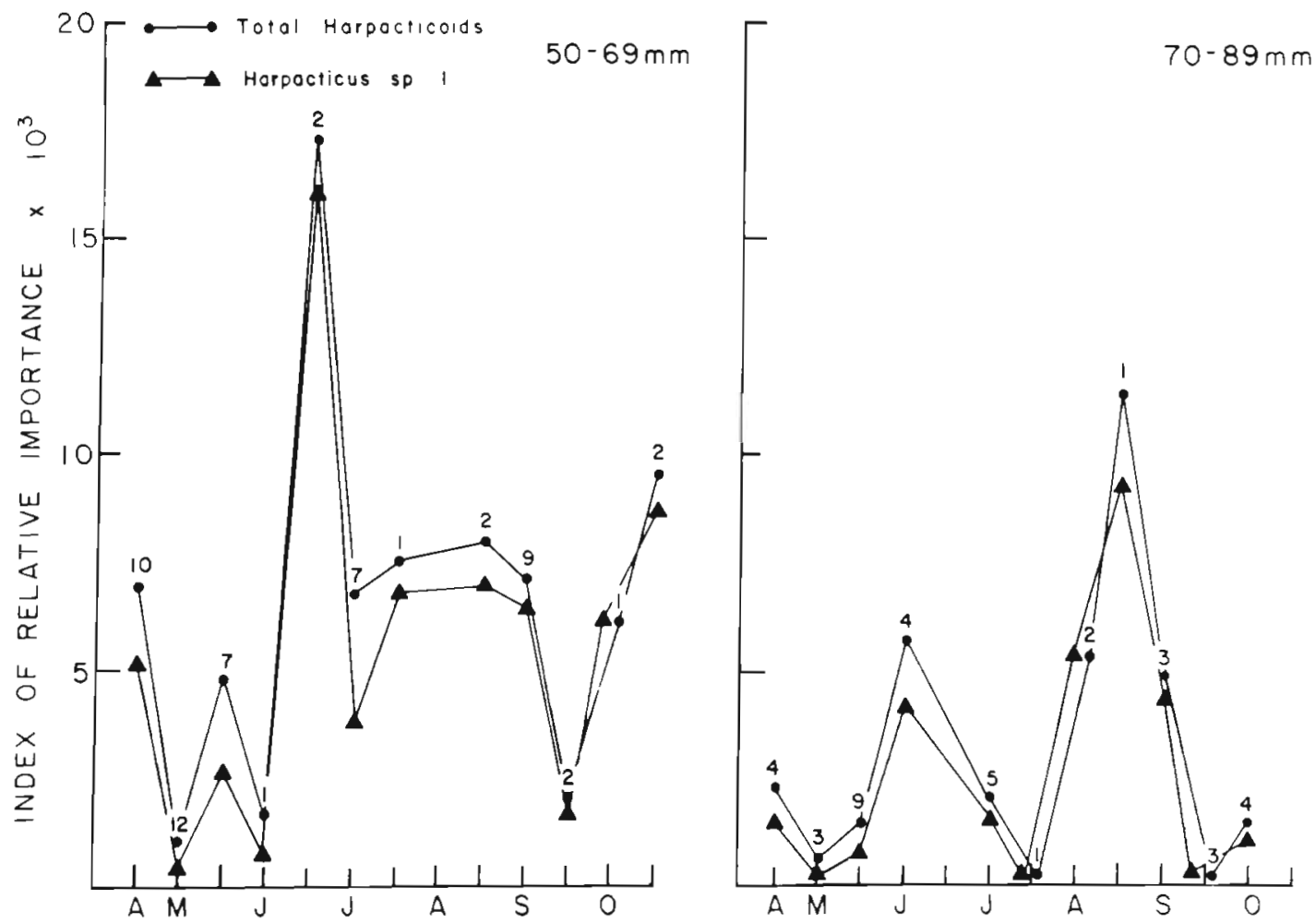

Fig. 3. Syngnathus scovelli. Temporal variation of Index of Relative Importance (IRI) values for total harpacticoid copepods and Harpacticus sp. 1 for the 50-69 $\mathrm{mm}$ and $70-89 \mathrm{~mm}$ size classes. Numbers of guts examined are indicated above data points. Dates same as in Fig. 2. Maximum IRI $=2.0 \times 10^{4}$ 
Table 4. Hippocampus zosterae. Percent frequency of occurrence $(\% \mathrm{~F})$ of major prey taxa for 3 size classes of fish. Number of guts examined is given in parentheses for each size class. Total $=\% \mathrm{~F}$ for all size classes combined

\begin{tabular}{|lrrrr|}
\hline Prey taxon & \multicolumn{5}{c}{ Size class in mm } & Total \\
& $<20$ & $20-30$ & $>30$ & \\
& $(n=15)$ & $(n=36)$ & $(n=36)$ & \\
\hline Amphipods & 13.3 & 41.7 & 44.7 & 36.8 \\
Calanoid copepods & 66.7 & 94.4 & 97.2 & 90.8 \\
Cyclopoid copepods & 33.3 & 44.4 & 25.0 & 34.5 \\
Harpacticoid copepods & 100.0 & 100.0 & 100.0 & 100.0 \\
Ostracods & 0.0 & 27.8 & 27.8 & 23.0 \\
Caridean shrimp & 0.0 & 5.6 & 0.0 & 2.3 \\
Unidentified copepods & 73.3 & 88.9 & 80.6 & 82.8 \\
& & & & \\
\hline
\end{tabular}

The diet of Hippocampus zosterae in terms of $\% \mathrm{~N}$ and $\%$ DW was dominated by harpacticoid copepods (Fig. 4) near or exceeding $80 \%$ of the diet of all size classes. Only unidentified copepods and calanoid copepods made up $>10 \%$ of the diet of any H. zosterae size class.

Harpacticoid copepods had IRI values greater than 15000 for all size classes of Hippocampus zosterae (Table 5). Calanold copepods and unidentified copepods were the only other prey with IRI values exceeding 1000. Amphipod IRI values increased
Table 5. Hippocampus zosterae. Index of Relative Importance (IRI) for prey items in 3 size classes of fish. Number of guts examined is given in parentheses for each size class (maximum IRI $\left.=2.0 \times 10^{-4}\right)$. Mean $=$ IRI for all size classes combined

\begin{tabular}{|lrrrr|}
\hline Prey taxon & \multicolumn{4}{c}{ Size class in mm } \\
& $<20$ & $20-30$ & $>30$ & Mean \\
& $(n=15)$ & $(n=36)$ & $(n=36)$ & \\
\hline Amphipods & 25 & 190 & 199 & 165 \\
Calanoid copepods & 786 & 1246 & 2196 & 1560 \\
Cyclopoid copepods & 221 & 112 & 13 & 90 \\
Harpacticoid copepods & 15348 & 15934 & 15432 & 15622 \\
Ostracods & 0 & 26 & 23 & 20 \\
Caridean shrimp & 0 & 3 & 0 & 1 \\
Unidentified copepods & 1919 & 1664 & 1389 & 1594 \\
\hline
\end{tabular}

slightly with increasing fish size but were generally small. Cyclopoid copepod IRI values were also small ranging from 221 for the $<20 \mathrm{~mm}$ size clases to 13 for the $>30 \mathrm{~mm}$ size class. Because harpacticoids dominated $\% \mathrm{~F}, \% \mathrm{~N}$ and $\% \mathrm{DW}$ over all dates, no strong seasonal pattern in feeding by $H$. zosterae was apparent. Thus by all measurements, harpacticoids were the overwhelmingly important prey item of $H$. zosterae.

Some seasonal variation in IRI values for total harpacticoids and for selected species of harpacticoids of all 3 size classes of Hippocampus zosterae was re-
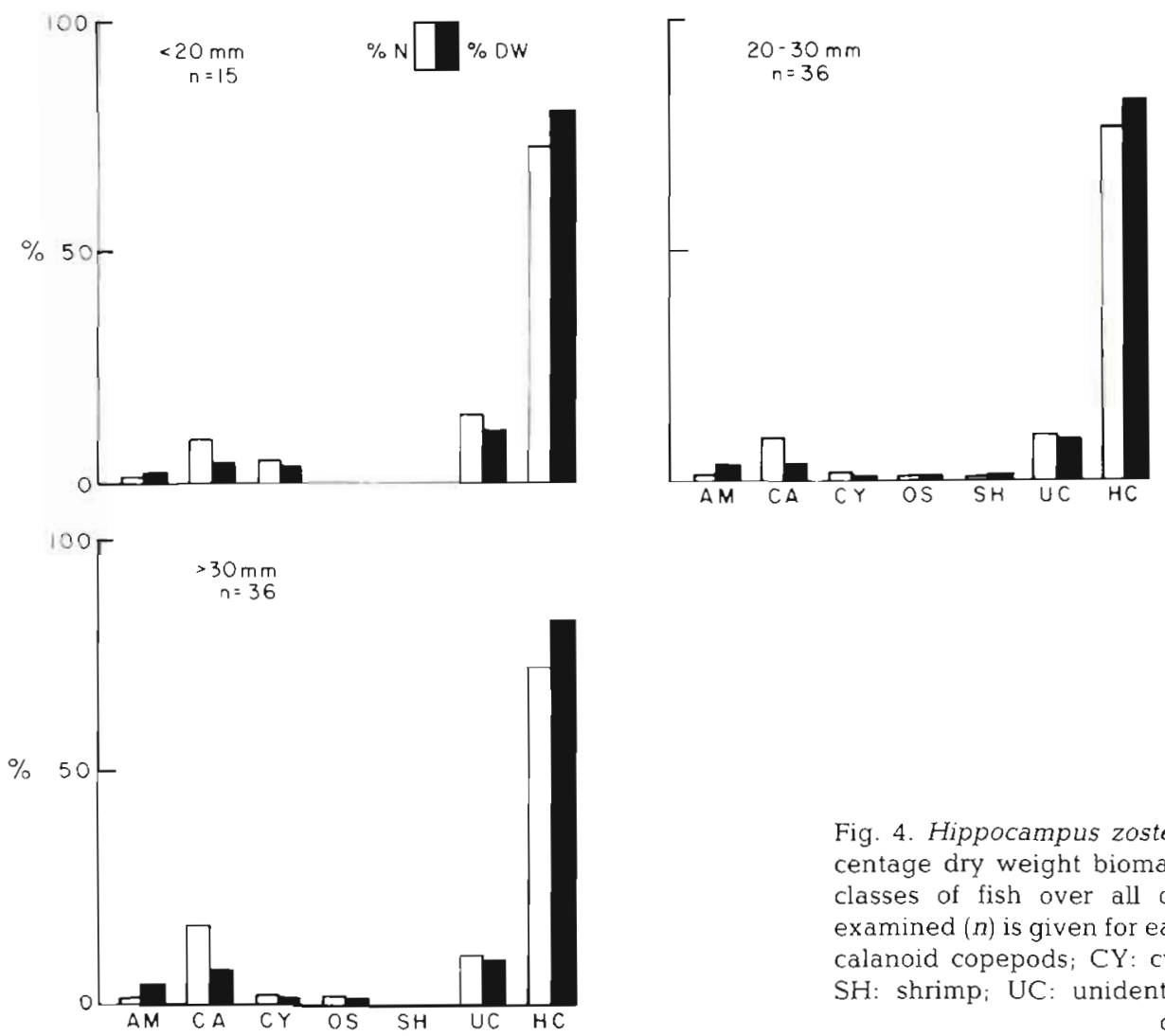

Fig. 4. Hippocampus zosterae. Percentage number and percentage dry weight biomass for prey items in guts of 3 size classes of fish over all dates combined. Number of guts examined $(n)$ is given for each size class. AM: amphipods; CA: calanoid copepods; CY: cyclopoid copepods; OS: ostracods; SH: shrimp; UC: unidentified copepods; HC: harpacticoid copepods 


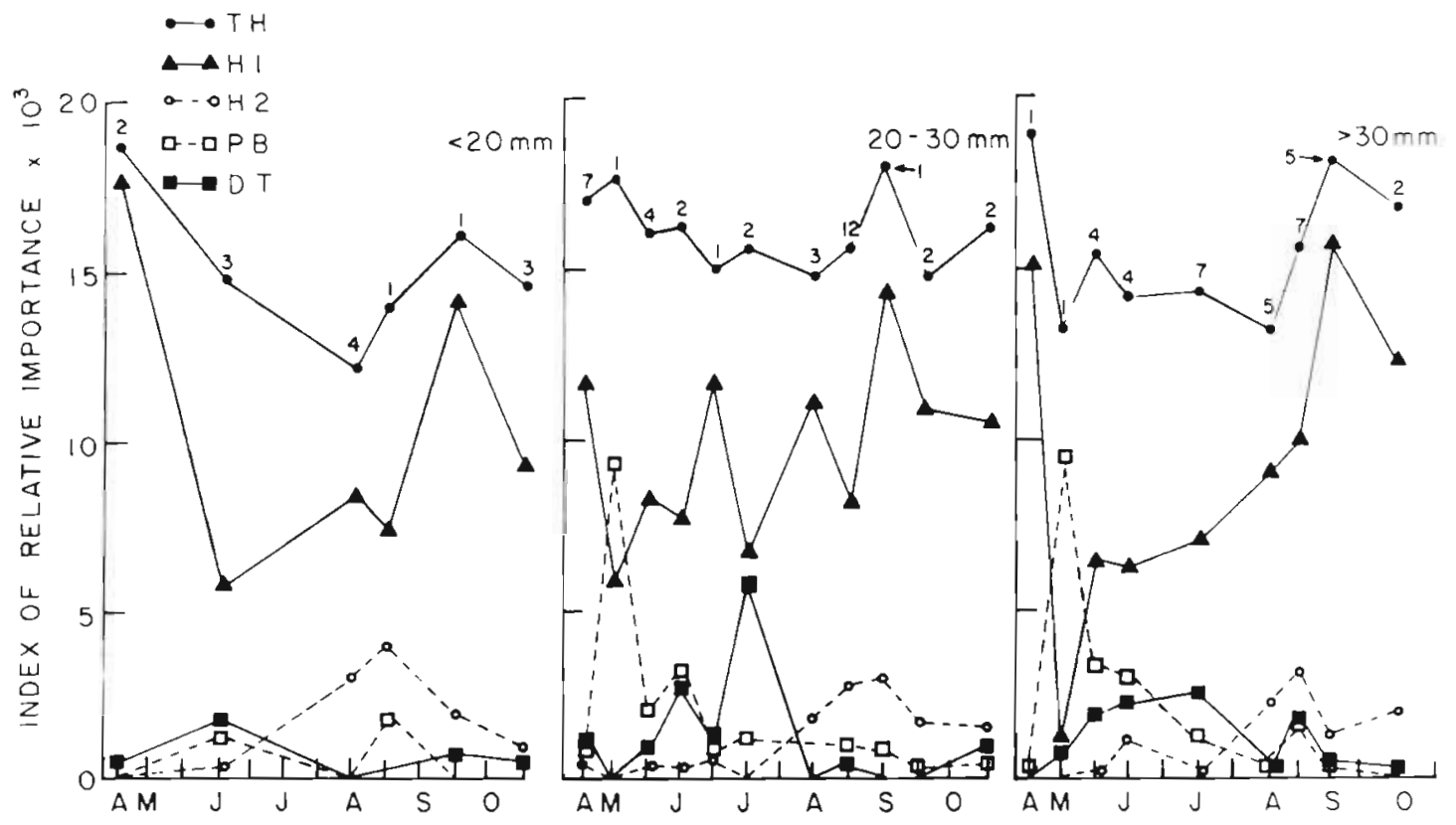

Fig. 5. Hippocampus zosterae. Temporal variation of Index of Relative Importance (IRI) values for total harpacticoid copepods and dominant harpacticoid copepod species for 3 size classes. Numbers of guts examined are indicated above data points. Dates same as Fig. 2. Maximum IRI $=2.0 \times 10^{4}$. TH: total harpacticoids; H1: Harpacticus sp. 1; $\mathrm{H} 2$ : Harpacticus sp. 2; PB: Paradactylopodia brevicornis; DT: Dactylopodia tisboides

corded (Fig. 5). Harpacticus sp. 1 was the dominant harpacticoid species in guts but 3 other species also were important to $H$. zosterae on selected dates. Paradactylopodia brevicornis had IRI values higher than Harpacticus sp. 1 in May for the $20-30 \mathrm{~mm}$ size class and $>30 \mathrm{~mm}$ size class. Harpacticus sp. 2 and Dactylopodia tisboides also were important prey species, but their IRI values never exceeded those of Harpacticus sp. 1.

\begin{abstract}
Available prey
Harpacticoid copepods were abundant on seagrass blades from the study site from April to October 1984 and were the dominant prey taxon on all dates sampled with a maximum abundance of 7.05 per $\mathrm{cm}^{2}$ of blade surface area in April (Tables 6 and 7 ). Other major prey taxa were less abundant. The harpacticoid Paradactylopodia brevicornis was abundant in the spring as was
\end{abstract}

Table 6. Mean number ( \pm SE) of dominant epifaunal crustaceans per $\mathrm{cm}^{2}$ on Thalassia testudinum blades, spring 1984. Only taxa found in guts of Syngnathus scovelli or Hippocampus zosterae are included. ( $N=4$ blades per date). Information on other copepod species is available in Tipton (1987)

\begin{tabular}{lcccc|}
\hline Taxon & 27 Apr & 11 May & 29 May & Total spring \\
\hline Amphipods & $0.47(0.27)$ & $0.08(0.03)$ & $0.02(0.02)$ & $0.18(0.10)$ \\
Caridean shrimp & $0.01(0.01)$ & $-0^{a}$ & - & $<0.01$ \\
Ostracods & $0.37(0.08)$ & $1.17(0.40)$ & $0.37(0.12)$ & $0.60(0.17)$ \\
Calanoid copepods & - & $<0.01$ & $0.03(0.02)$ & $0.01(0.01)$ \\
Cyclopoid copepods & $0.07(0.03)$ & $0.42(0.13)$ & $0.04(0.02)$ & $0.18(0.07)$ \\
Total harpacticoid copepods & $7.07(1.70)$ & $3.28(0.70)$ & $1.70(0.81)$ & $3.99(0.03)$ \\
Unidentified copepodites & $1.72(0.25)$ & $0.52(0.09)$ & $0.27(0.12)$ & $0.87(0.21)$ \\
Harpacticus sp. 1 & $0.01(0.01)$ & $0.02(0.01)$ & $<0.01$ & $0.01(0.00)$ \\
Harpacticus sp. 2 & $0.57(0.14)$ & $0.12(0.05)$ & $0.17(0.09)$ & $0.27(0.80)$ \\
Dactylopodia tisboides & $0.55(0.18)$ & $0.15(0.07)$ & $0.17(0.08)$ & $0.22(0.64)$ \\
Paradactylopodia brevicornis & $1.05(0.26)$ & $0.67(0.22)$ & $0.67(0.42)$ & $0.87(0.19)$ \\
Taxon not present & & & & \\
\hline
\end{tabular}


Table 7. Mean number ( $\pm \mathrm{SE}$ ) of dominant epifaunal crustaceans per $\mathrm{cm}^{2}$ of Thalassia testudinum blades, summer 1984 . Only taxa found in guts of Syngnathus scovelli or Hippocampus zosterae are included. ( $N=4$ blades per date). Information on other copepod species is available in Tipton (1987)

\begin{tabular}{|lcccc|}
\hline Taxon & 24 Aug & 7 Sep & 21 Sep & Total summer \\
\hline Amphipods & $0.02(0.18)$ & $-{ }^{\mathrm{a}}$ & $0.07(0.01)$ & $0.28(0.01)$ \\
Caridean shrimp & - & - & $0.01(0.01)$ & $<0.01$ \\
Ostracods & $0.23(0.01)$ & $0.20(0.13)$ & $0.19(0.07)$ & $0.20(0.03)$ \\
Calanoid copepods & $0.04(0.03)$ & $0.31(0.55)$ & $0.05(0.04)$ & $0.13(0.56)$ \\
Cyclopoid copepods & $0.06(0.03)$ & $0.12(0.05)$ & $0.70(0.25)$ & $0.29(0.12)$ \\
Total harpacticoid copepods & $2.39(0.37)$ & $4.18(0.36)$ & $1.68(0.71)$ & $2.75(0.41)$ \\
Unidentified copepodites & $0.96(0.14)$ & $1.76(0.36)$ & $0.40(0.17)$ & $1.04(0.21)$ \\
Harpacticus sp. 1 & $0.01(0.01)$ & $0.05(0.02)$ & - & $0.02(0.01)$ \\
Harpacticus sp. 2 & $0.60(0.17)$ & $1.53(0.19)$ & $0.34(0.15)$ & $0.82(0.18)$ \\
Dactylopodia tisboides & $0.04(0.02)$ & $0.48(0.15)$ & $0.31(0.15)$ & $0.28(0.08)$ \\
Paradactylopodia brevicornis & $0.54(0.15)$ & $0.24(0.10)$ & $0.28(0.17)$ & $0.35(0.08)$ \\
a Taxon not present & & & & \\
\hline
\end{tabular}

Harpacticus sp. 2 in late summer. Harpacticus sp. 1 had very low abundances from blades on all 6 sampling dates. Unidentified copepodites were found in high densities in both spring and summer with 1.76 per $\mathrm{cm}^{2}$ of blade surface in early September.

\section{Selectivity of prey by Syngnathus scovelli and Hippocampus zosterae}

Vanderploeg \& Scavia's Electivity Index (E*) for Syngnathus scovelli and Hippocampus zosterae indicated that most major prey taxa were avoided $(77 \%$ of cases) by all size classes of both $S$. scovelli (Table 8) and $H$. zosterae (Table 9). Only $14 \%$ of cases were assigned 'random' feeding. Few prey taxa were selected. Calanoid copepods were selected by the $50-69 \mathrm{~mm}$ and $70-89 \mathrm{~mm} \mathrm{~S}$. scovelli in spring and cyclopoid copepods by $>30 \mathrm{~mm}$ S. scovelli in summer (Table 8). Hippocampus zosterae $<20 \mathrm{~mm}$ selected cyclopoids in summer and $>30 \mathrm{~mm} \mathrm{H}$. zosterae selected calanoids in spring (Table 8). Harpacticus sp. 1 was the only harpacticoid copepod prey species which was selected by $S$. scovelli or $H$. zosterae, being chosen disproportionately to its field abundance by all size classes in spring and summer (Tables 8 and 9).

\section{DISCUSSION}

Harpacticoid copepods comprised the largest percentage of the diet of Hippocampus zosterae and the small size classes of Syngnathus scovelli in the Tampa Bay, Florida, seagrass bed. S. scovelli (size class unidentified) from a Texas seagrass bed also had a large proportion of copepods in gut samples (Huh \&

Table 8. Vanderploeg \& Scavia's Electivity Index $\left(E^{*}\right)$ for major prey taxa and dominant harpacticoid copepod species in guts of Syngnathus scovelli in spring and late summer 1984 . $E^{*}$ ranges from +1 (selectivity) to -1 (avoidance)

\begin{tabular}{|c|c|c|c|c|c|c|c|c|}
\hline \multirow[t]{3}{*}{ Prey organism } & \multicolumn{8}{|c|}{ Size class in $\mathrm{mm}$} \\
\hline & \multicolumn{2}{|c|}{$<30$} & \multicolumn{2}{|c|}{$30-49$} & \multicolumn{2}{|c|}{$50-69$} & \multicolumn{2}{|c|}{$70-89$} \\
\hline & Spring & Summer & Spring & Summer & Spring & Summer & Spring & Summer \\
\hline Amphipods & -1.00 & -1.00 & -0.90 & +0.15 & -0.69 & -0.48 & -0.24 & -0.41 \\
\hline Calanoid copepods & -1.00 & -0.32 & +0.18 & -0.64 & +0.67 & 0.00 & +0.78 & +0.09 \\
\hline Cyclopoid copepods & -0.34 & +0.71 & -0.75 & -0.96 & -0.87 & -0.98 & -0.07 & -0.97 \\
\hline Ostracods & -1.00 & -1.00 & -1.00 & -1.00 & -0.99 & -1.00 & -0.99 & -0.99 \\
\hline Caridean shrimp & -1.00 & -0.08 & -0.73 & -0.63 & +0.02 & -0.84 & -0.26 & -0.37 \\
\hline Total harpacticoid copepods & -0.02 & -0.94 & -0.72 & -0.73 & -0.88 & -0.65 & -0.95 & -0.76 \\
\hline Unidentified copepodites & -0.03 & -0.99 & -0.96 & -0.99 & -0.96 & -0.99 & -0.97 & -0.99 \\
\hline Harpacticus sp. 1 & +0.43 & +0.55 & +0.85 & +0.80 & +0.85 & +0.83 & +0.44 & +0.77 \\
\hline Harpacticus sp. 2 & -1.00 & -1.00 & -0.99 & -0.97 & -0.96 & -0.97 & -1.00 & -0.98 \\
\hline Dactylopodia tisboides & -1.00 & -1.00 & -1.00 & -1.00 & -1.00 & -0.99 & -0.99 & -1.00 \\
\hline Paradactylopodia brevicornis & -1.00 & -1.00 & -0.99 & -1.00 & -0.96 & -0.99 & -0.95 & -0.99 \\
\hline
\end{tabular}


Table 9. Vanderploeg \& Scavia's Electivity Index $\left(E^{*}\right)$ for major prey taxa and dominant harpacticoid species from guts of Hippocampus zosterae in the spring and late summer 1984. $E^{\prime}$ ranges from +1 (selectivity) to -1 (avoidance)

\begin{tabular}{|c|c|c|c|c|c|c|}
\hline \multirow[t]{2}{*}{ Prey organism } & \multicolumn{6}{|c|}{ Size class in $\mathrm{mm}$} \\
\hline & Spring & Summer & Spring & Summer & Spring & Summer \\
\hline Amphipods & -0.97 & -0.59 & -0.88 & -0.72 & -0.77 & -0.88 \\
\hline Calanoid copepods & -0.59 & -0.95 & +0.09 & -0.19 & +0.33 & -0.30 \\
\hline Cyclopoid copepods & -1.00 & +0.98 & -0.86 & -0.99 & -0.94 & -0.99 \\
\hline Ostracods & -1.00 & -1.00 & -0.99 & -0.99 & -0.99 & -1.00 \\
\hline Caridean shrimp & -1.00 & -1.00 & -1.00 & -0.50 & -1.00 & -1.00 \\
\hline Total harpacticoid copepods & -0.62 & -0.24 & -0.46 & -0.22 & -0.59 & -0.23 \\
\hline Unidentified copepodites & -1.00 & -1.00 & -0.88 & -0.97 & -0.93 & -0.99 \\
\hline Harpacticus sp. 1 & +0.70 & +0.76 & +0.88 & +0.86 & +0.88 & +0.87 \\
\hline Harpacticus sp. 2 & -1.00 & -0.95 & -0.89 & -0.84 & -0.97 & -0.92 \\
\hline Dactylopodia tisboides & -0.99 & -0.96 & -0.84 & -0.93 & -0.79 & -1.00 \\
\hline Paradactylopodia brevicornis & -1.00 & -0.99 & -0.92 & -0.86 & -0.84 & -0.95 \\
\hline
\end{tabular}

Kitting 1985). Given that the small size classes of seagrass resident fishes such as the pinfish Lagodon rhomboides (Stoner 1979, Livingston 1980), spot Leiostomus xanthurus (Sheridan \& Livingston 1979), mojarra Eucinostomus gula, and silver perch Bairdiella chrysura (Livingston 1982) utilize harpacticoid copepods as prey, the dietary patterns observed for syngnathids in our study site are not unique. Moreover, because patterns of abundances for S. scovelli and $H$. zosterae in Tampa Bay, Florida (Tipton 1987), as well as dietary characteristics reported here, in general accord with reports from other geographical areas, a common feeding pattern emerges for these fishes in seagrass beds.

The diet of Syngnathus scovelli changed ontogenetically from harpacticoid copepods to larger prey as fish size increased (Table 2; Fig. 2). The ontogenetic switch from small prey to larger prey was also shown for $S$. scovelli from Appalachicola Bay, Florida (Livingston. 1982,1984 ), but harpacticoids were not as prevalent in the diet as in the present study. Syngnathus fuscus from North Carolina (Adams 1976) and Chesapeake Bay (Ryer 1981) also switched from smaller to larger prey as adult fish size increased but no information is available to determine if a strong dependence on harpacticoids by juveniles of $S$. fuscus existed.

In contrast to Syngnathus scovelli, little ontogenetic change was apparent in Hippocampus zosterae diets with a strong dominance of harpacticoid copepods over all size classes (Fig. 5) and dates (Tipton 1987). This is the first study to report harpacticoids as important prey of H. zosterae. Reid (1954) found shrimp and microcrustaceans to be the major prey of seahorses near Cedar Key, Florida. Shrimp were found in only 2 guts of $H$. zosterae in the present study, but Reid (1954) lumped all seahorse species together for diet descriptions and was probably including shrimp eaten by larger seahorse species. Brook (1977) mentioned that the gut contents of $H$. zosterae from Biscayne Bay, Florida, passed through a $1 \mathrm{~mm}$ mesh sieve, perhaps indicating that small prey like harpacticoid and cyclopoid copepods were eaten.

Information on prey selectivity of syngnathids is limited. Ryer (1981) found that Syngnathus fuscus $(<100 \mathrm{~mm})$ selected calanoid copepods in June and November and various species of amphipods and isopods in other months. The larger size classes (50-69 mm, 70-89 mm) of Syngnathus scovelli in this study also selected calanoid copepods in the spring. Total harpacticoid copepods which had the highest IRI values were not selected by $S$. scovelli, although the dominant harpacticoid species, Harpacticus sp. 1, in the gut was selectively chosen. Prey selectivity of Hippocampus zosterae was similar to that of S. scovelli, (Tables 8 and 9) but some differences in diet content are notable, probably attributable to differences in food capturing behavior and the syngnathids' size. $H$. zosterae, being smaller and less motile than S. scovelli, may not be able to capture the larger and more mobile prey, such as amphipods and shrimp, since small fishes are particularly ineffective at capturing large, motile prey (Eggers 1977). These bigger prey would be more susceptible to predation by $S$. scovelli, especially the large sizes. A similar explanation was offered by Howard \& Koehn (1985) for Australian syngnathids. They found Urocampus carinorostris, the smallest of 4 pipefish species examined, to have had the highest percentage of harpacticoids in its diet. $U$. carinorostris has a prehensile tail and uses a 'sit and wait type feeding behavior, similar to that of $H$. zosterae, which Howard \& Koehn (1985) maintain may restrict ability to capture mobile prey such as amphipods. Behavioral differences between syngnathids may thus be important in this study.

In general, selectivity values need to be interpreted 
cautiously. What is deemed available prey by a researcher may not be available to a predator due to behavior of the predator, behavior of the prey, area sampled or the sampling method employed (Eggers 1977, Petraitis 1979). Determining prey availability in estuaries may be especially difficult for mobile organisms since prey may reside in more than one microhabitat (Minello \& Zimmerman 1984). The sampling method chosen for this study was designed to efficiently capture meiobenthos on blades but underestimated planktonic prey such as cyclopoid and calanoid copepods. The larger, more mobile crustaceans, such as shrimp and amphipods, probably avoided the sampling tube. These 2 sources of possible sampling bias would tend to cause the $E^{*}$ values of these more mobile organisms to be overestimated and the selectivity of other organisms, such as harpacticoids, to be undervalued. As such, the evaluation of strong selectivity for any harpacticoid is probably conservative. Moreover, a consistent pattern of relative abundances for major taxa and harpacticoid copepod species on blades from various dates was observed (Tables 6 and 7); therefore the lumping of 3 dates for electivity calculations was justified (see 'Materials and Methods').

The harpacticoid copepod Harpacticus sp. 1 was always selected by all sizes of both Syngnathus scovelli and Hippocampus zosterae. Although very little is known about the life history of Harpacticus sp. 1, many factors may contribute to its attractiveness as prey for S. scovelli and H. zosterae. First, the behavior of Harpacticus sp. 1 may be important as motion has been identified as the best single predictor of predator risk for planktonic prey of brown trout (Ware 1973). Second, the high selectivity values of Harpacticus sp. 1 reflected extremely low abundance on seagrass blades (available prey). Two possible explanations can be offered. First, the microhabitat of Harpacticus sp. 1 within the grassbed is unknown and the sampling regime chosen for this study may not have accurately predicted available prey (see above). An attempt was made to more widely assess the microhabitat utilization of Harpacticus sp. 1 by sampling the water column around and above the seagrass blades, sediment near the blades, and drift algae. Very few Harpacticus sp. 1 were found in any of these sampling efforts suggesting that the low numbers in the field may not be a sampling artifact. Alternatively, predation by Syngnathus scovelli and Hippocampus zosterae could be responsible for the low numbers of Harpacticus sp. 1 collected in samples from the grassbed. Guts with over 100 Harpacticus sp. 1 each were not uncommon for either fish species and as many as 200 individuals per gut were found in $H$. zosterae guts. Predation at this level could keep the population of Harpacticus sp. 1 low and alternatively might explain the low abundances of this species in all the samplings. Sibert (1979) found a similar situation for harpacticoids in the Nanaimo estuary, British Columbia. Harpacticus uniremis was the dominant prey species of the chum salmon Oncorhyncus keta (Healey 1979), but was rare in sediment core samples. Because very few studies have looked at copepod prey at the species level it is impossible to know if this is a general phenomenon.

Attempts have been made to determine whether fish predation controls harpacticoid copepod populations with contrasting views offered in other studies. Many authors maintain that fish predation exerts little regulatory control on harpacticoid populations (Bregnballe 1961, Sibert et al. 1977. Alheit \& Scheibel 1982, Sogard 1984, Hicks 1985). Feller \& Kaczynski (1975), however, observed a decrease in densitites of benthic harpacticoids by 3 orders of magnitude from April to May in Puget Sound coinciding with the influx of juvenile salmon and suggested that the salmon predation was responsible for the decrease. Sibert (1979) and Gee et al. (1985) provided evidence for fish predation having a controlling influence on a single harpacticoid species but not the total abundance of copepods. In the Tampa Bay seagrass bed, a high level of predation combined with very low abundances of Harpacticus sp. 1 on the seagrass blades could suggest that the population of this copepod species is being controlled by syngnathid predation, although further experimentation is necessary to test this hypothesis.

It is clear that harpacticoid copepods are entwined in the trophic network of the seagrass bed examined here. While the position of syngnathids in the food web is not firmly established because little is known about predation on these fishes (Strawn 1958, Lascara 1981, Howard \& Koehn 1985), their continued appearance as common or dominant fishes in seagrass beds suggests that they may provide a significant energy source. Accordingly, the large numbers of harpacticoids eaten by these syngnathids provides evidence that the fishcopepod link is integral to seagrass ecosystem function.

Acknowledgements. We thank Drs B. C. Cowell and H. R Mushinsky and anonymous reviewers for their critical reviews and/or discussions concerning this project. The following persons provided much needed assistance with field collections and computer analyses: M. Mann, M. Vitale, D. Miller and W. Bros. This work was completed in partial fulfillment of the requirements for a Master of Science degree in Zoology (K. T.) at the University of South Florida.

\section{LITERATURE CITED}

Adams, S. M. (1976). Feeding ecology of eelgrass fish communities. Trans. Am. Fish. Soc. 105: 514-519

Alheit, J., Scheibel, W (1982). Benthic harpacticoids as a food source for fish. Mar Biol. 70: 141-147 
Bell, S. S., Walters, K., Kern, J. C. (1984). Sampling for meiofaunal taxa in seagrass systems: lessons from studies in a subtropical Florida estuary, U.S.A. In: Thompson, M. F., Sarojini, R., Nagabushabam, R. (eds.) Biology of benthic marine organisms. Oxford and IBH, New Delhi, p. 239-245

Bodiou, J. Y., Villiers, L. (1979). La predation de la meiofaune par les formes juveniles de Deltentosteus quadrimaculatus (Teleostei, Gobiidae). Vie Milieu 29: 143-156

Bregnballe, F. (1961). Plaice and flounders as consumers of the microscopic bottom fauna. Meddr Danm. Fisk.-og. Havunders. 3: 133-182

Brook, I. M. (1977). Trophic relationships in a seagrass community (Thalassia testudinum), in Card Sound, Florida Fish diets in relation to macrobenthic and cryptic faunal abundance. Trans. Am. Fish. Soc. 106: 219-229

Carr, W. E. S., Adams, C. A. (1973). Food habits of juvenile marine fishes occupying seagrass beds in the estuarine zone near Crystal River, Florida. Trans. Am. Fish. Soc. 106 : $511-540$

Chesson, J. (1978). Measuring preference in selective predation. Ecology 59: 211-215

Eggers, D. M. (1977). Prey selection by planktivorous fish. Ecology 58: 46-59

Feller, R. J., Kaczynski, V W. (1975). Size selective predation by juvenile chum salmon (Oncorhyncus keta) on epibenthic prey in Puget Sound. J. Fish. Res. Bd Can. 32 : $1419-1429$

Fulton, R. S. (1985). Predator-prey relationships in an estuarine littoral copepod community. Ecology 66: 21-29

Gee, J. M., Warwick, A. M., Davey, J. J., George, C. L. (1985). Field experiments on the role of epibenthic predators in determing prey densities in an estuarine mudflat. Estuar. coast. Shelf Sci. 21. 429-448

Healey, M. C. (1979). Detritus and juvenile salmon production in the Nanaimo Estuary. I. Production and feeding rates of juvenile chum salmon (Oncorhyncus keta). J. Fish. Res. Bd Can. 36: $488-496$

Heip, C., Smol, N. (1976). On the importance of Protohydra leuckarti as a predator of meiobenthic populations. In: Persoone, G., Jaspers, E. (eds.) Proceedings of 10 th European Marine Biology Symposium, Vol. 2. Universa Press, Wetteren, p. 285-296

Hicks, G. R. F. (1985). Biomass and production estimates for an estuarine meiobenthic copepod, with instantaneous assessment of exploitation by flatfish predators. N. Z. J. Ecol. 8: 123-125

Howard, R. K., Koehn, J. D. (1985). Population dynamics and feeding ecology of pipefish (Syngnathidae) associated with eelgrass beds of Western Port, Victoria. Aust. J. mar Freshwat. Res. 36: 361-370

Huh, S. H. (1984). Seasonal variation in populations of small fishes concentrated in shoalgrass and turtlegrass meadows. J. Oceanol. Soc. Korea 19: 44-55

Huh, S. H., Kitting, C. L. (1985). Trophic relationships among concentrated populations of small fishes in seagrass meadows. J. exp. mar Biol. Ecol. 92: 29-43

Hyslop, E. J. (1980). Stomach contents analysis - a review of methods and their applications. J. Fish Biol. 17. 411-429

Kulczycki, G. R., Virnstein, R. W., Nelson, W. G. (1981). The relationship between fish abundances and algal biomass in a seagrass-drift algae community. Estuar, coast. Shelf Sci. 12: 341-347

Lascara, J. (1981). Fish predator-prey interactions in areas of eel grass (Zostera marina). M.S. thesis, School of Marine Science, College of William and Mary, Williamsburg

Lechowitz, M. J. (1982). The sampling characteristics of electivity indices. Oecologia (Berl.) 52: 22-30
Livingston, R. J. (1980). Ontogenetic trophic relationships and stress in a coastal seagrass system in Florida. In: Kenneday, V. S. (ed.) Estuarine perspectives. Academic Press, New York, p. 423-435

Livingston, R. J. (1982). Trophic organization of fishes in a coastal seagrass systems. Mar. Ecol. Prog. Ser. 7: 1-12

Livingston, R. J. (1984). Trophic responses of fishes to habitat variability in coastal seagrass systems. Ecology 65 $1258-1275$

Marshall, N. (1970). Food transfer through the lower trophic levels of the benthic environment. In: Steele, J. H. (ed.) Marine food chains. Oliver and Boyd, Edinburgh, p. 19-31

McIntyre, A. D., Murison, D. J. (1973). The meiofauna of a flatfish nursery ground. J. mar. biol. Ass. U. K. 53: 93-118

Minello, J., Zimmerman, R. J. (1984). Selection for brown shrimp, Penaeus aztecus, as prey by the spotted seatrout, Cynoscion nebulosus. Contr. mar. Sci. 27: 159-167

Nelson, W. G. (1979). Experimental studies of selective predation on amphipods: consequences for amphipod distribution and abundance. J. exp. mar. Biol. Ecol. 38: 225-245

Petraitis, P. S. (1979). Likelihood measures of niche breadth and overlap. Ecology 60: 703-710

Pinkas, L., Oliphant, M. S., Iverson, I. L. K. (1971). Food habits of albacore, blue fin tuna and bonito in California waters. Dept. Fish Game Bull. Cal. 152: 1-105

Reid, G. K. (1954). An ecological study of the Gulf of Mexico fishes in the vicinity of Cedar Key, Florida. Bull. mar. Sci. (Gulf Caribb.) 4: 1-94

Robertson, A. I. (1977). The ecology of juvenile King George Whiting, Sillaginodes punctatus (Cuvier and Valeciennes) (Pisces: Perciformes), in Western Port, Victoria. Aust. J. mar. Freshwat. Res. 28: 35-43

Ryer, C. H. (1981). The feeding ecology and trophic role of the northern pipefish, Syngnathus fuscus, in a lower Chesapeake Bay seagrass community. M. A. thesis, School of Marine Science, College of William and Mary, Williamsburg

Ryer, C. H., Boehlert, G. W. (1983). Feeding chronology, daily ration, and the effects of temperature upon gastric evacuation in the pipefish, Syngnathus fuscus. Environ. Biol. Fish. 9: 301-306

Sheridan, P. F., Livingston, R. J. (1979). Cyclic trophic relationships of fishes in an unpolluted, river-dominated estuary in north Florida. In: Livingston, R. J. (ed.) Ecological processes in coastal and marine systems. Plenum Press, New York, p. 143-161

Sibert, J. R. (1979). Detritus and juvenile salmon production in the Nanaimo Estuary: II. Meiofauna available as food to juvenile chum salmon (Oncorhyncus keta). J. Fish. Res. Bd Can. 36: 497-502

Sibert, J. R., Brown, T J., Healey, M. C., Kask, B. A. (1977). Detritus-based food webs: exploitation by juvenile chum salmon (Oncorhyncus keta). Science 196: 649-650

Sogard, S. M. (1982). Feeding ecology, population structure and community relationships of a grassbed fish, Callionymus pauciradiatus, in southern Florida. M. S. thesis, Univ. of Miami, Coral Gables

Sogard, S. M. (1984). Utilization of meiofauna as a food source by a grassbed fish, the spotted dragonet, Callionymus pauciradiatus. Mar. Ecol. Prog. Ser. 17: 183-191

Stoner, A. W. (1979). Species-specific predation on amphipod crustacea by pinfish (Lagodon rhomboides): mediation by macrophyte standing crop. Mar Biol. 55: 201-207

Stoner, A. W. (1980). The feeding ecology of Lagodon rhomboides (Pisces: Sparidae): variation and functional responses. Fish. Bull. Fish Wildi. Serv. U. S. 78: 337-352

Stoner, A. W. (1982). The influence of benthic macrophytes on 
the foraging behavior of pinfish, Lagodon rhomboides (Linnaeus). J. exp. mar Biol. Ecol. 58: 271-284

Stoner, A. W., Livingston, R. J. (1984). Ontogenetic patterns in diet and feeding morphology in sympatric sparid fishes from seagrass meadows. Copeia 1984: 174-187

Strawn, K. (1954). The pushnet, a one-man net for collecting in attached vegetation. Copeia 1954: 195-197

Strawn, K. (1958). Life history of the pygmy seahorse, Hippocampus zosterae (Jordan and Gilbert), at Cedar Key Florida. Copeia 1958: 16-22

Targett, T E. (1984). A breeding population of gulf pipefish (Syngnathus scovelli) in a Georgia estuary, with discussion on the ecology of the species. Contr. mar. Sci. 27; 169-174

Tipton, K. (1987). The feeding ecology of two syngnathids in a Tampa Bay, Florida seagrass bed: with special reference to harpacticoid copepods. M. S. thesis, Univ. of South Florida Tampa
Vanderploeg, H. A., Scavia, D. (1979). Two electivity indices for feeding with special reference to zooplankton grazing. Can. J. Fish. aquat. Sci. 36: 362-365

Ware, D. M. (1973). Risk of epibenthic prey to predation by Rainbow trout (Salmo gairdneiri). J. Fish. Res. Bd Can. 30: 787-797

Williams, R., Robins, D. B. (1982). Effects of preservation on wet weight, dry weight, nitrogen and carbon contents of Calanus helgolandicus (Crustacea: Copepoda). Mar. Biol. 71: 271-281

Young, D. K., Buzas, M. A., Young, M. W. (1976). Species density of macrobenthos associated with seagrass: a field experimental study of predation. J. mar. Res. 34: 577-592

Zander, C. D. (1982). Feeding ecology of littoral gobiid and blennioid fish of the Banyul's area (Mediterranean Sea): I. Main food and trophic dimension of niche ecotope. Vie Milieu 32: 1-10

This article was submitted to the editor; it was accepted for printing on May 9, 1988 